\title{
$\mathrm{Pt} / \mathrm{CeO}_{2}$ with residual chloride as reusable soft Lewis acid catalysts: application to highly efficient isomerization of allylic esters
}

\author{
Qi-An Huang \\ Kyushu University \\ Asahi Haruta \\ Kyushu University

\section{Yuhya Kumamoto} \\ Kyushu University
}

Haruno Murayama ( $\nabla$ haruno9@chem.kyushu-univ.jp )

Kyushu University

\section{Eiji Yamamoto}

Kyushu University

\section{Tetsuo Honma}

Japan Synchrotron Radiation Research Institute (JASRI)/SPring-8

\section{Mitsutaka Okumura}

Osaka Univesity https://orcid.org/0000-0001-7403-1318

Hiroki Nobutou

Osaka University

Makoto Tokunaga

Kyushu University

\section{Article}

Keywords: Heterogeneous Acid and Base Catalysts, Highly Dispersed Supported Platinum Catalyst, Solvent-free Conditions, Pt-Cl bonds

Posted Date: January 19th, 2021

DOI: https://doi.org/10.21203/rs.3.rs-86545/v1

License: (c) (i) This work is licensed under a Creative Commons Attribution 4.0 International License. Read Full License 


\section{Abstract}

Heterogeneous acid and base catalysts play a crucial role in many important chemical processes. Hard Lewis and Brønsted acid catalysts like silica-alumina and zeolites have been widely applied in numerous reactions; however, developing reusable and active soft Lewis acid catalysts remain a challenge. Herein, we demonstrate for the first time that a highly dispersed supported platinum catalyst can act as a heterogeneous soft Lewis acid. High turnover numbers and reusability were observed in the isomerization of allylic esters under solvent-free conditions. Moreover, the as-prepared catalysts are characterized by Xray photoelectron spectroscopy (XPS) and X-ray absorption fine structure (XAFS) analyses, revealing that the highly dispersed Pt clusters with $\mathrm{Pt}-\mathrm{Cl}$ bonds play a key role in the high activity. The residual chloride anion enhances the Lewis acidity of the Pt metal center and thus improves the catalytic activity. Simultaneously, the high catalytic activity of $\mathrm{Pt} / \mathrm{CeO}_{2}$ with residual chloride and the soft Lewis acid mechanism are also proved by density functional theory (DFT) calculations based on the model reaction.

\section{Introduction}

Supported platinum catalysts have been extensively researched and proven to play crucial roles in multiple applications, such as fuel cells $s^{1,2}$, automotive three-way catalysts ${ }^{3,4}$, catalytic redox reactions ${ }^{5,6}$, and value-added fine chemical reactions ${ }^{7,8}$. Here, most applications of supported Pt catalysts are based on the redox function. In contrast, to the best of our knowledge, there are no reports on the supported Pt catalysts utilizing soft Lewis acidity, although homogenous Pt(II) complexes have been employed in the hydration of alkynes and nitriles ${ }^{9-12}$, isomerization of allylbenzenes ${ }^{13}$, cyclization of alkynes ${ }^{14}$, etc. Thus, a heterogeneous supported platinum catalyst with soft Lewis acid function would be a promising practical catalyst.

According to Pearson's hard-soft acid-base (HSAB) principle, Lewis acids are classified into hard and soft acids which can activate corresponding hard or soft base ${ }^{15}$. In many industrial reactions, zeolites, typical hard acids, have been widely used ${ }^{16,17}$, including fluid catalytic cracking as commercial catalysts. On the other hand, most reactions based on soft Lewis acids have still been developed over homogeneous metal catalysts. The low-valent noble metals have soft characteristics and thus should function as a soft Lewis acid to activate soft bases, i.e., p electrons of $\mathrm{C}-\mathrm{C}$ double and triple bonds, to undergo nucleophilic attack with various nucleophiles. Although these catalysts provide many useful synthetic applications, the poor reusability and small turnover numbers (TONs) hinder their practical utility; therefore, their applications remain limited.

Over the last decade, several catalytic reactions over recyclable supported Au nanoparticles as a soft Lewis acid were reported. Corma et al. ${ }^{18,19}$, Parida et al. ${ }^{20}$, and Zhao et al ${ }^{21}$. reported catalytic hydroamination with supported Au catalysts. Gryparis et al ${ }^{22}$. realized the cyclization of 1,6-enynes with $\mathrm{TiO}_{2}$-supported Au nanoparticles. Toste and Somorjai et $\mathrm{al}^{23}$. also successfully used supported $\mathrm{Au}$ nanoparticles with N-heterocyclic carbene for lactonization. In Lewis acid-base catalysis, the 
counteranion is important to expand the Lewis acid function. The stronger the conjugated acid of the counteranion is, the greater the Lewis acidity displayed by the central metal. Lewis acidity can also be enhanced when the cation is isolated, as in frustrated Lewis pairs ${ }^{24}$. However, soft cations such as $\mathrm{Au}(\mathrm{I})$ and $\mathrm{Pd}(\mathrm{II})$ are easily reduced to zero valences and easily aggregate, which makes it difficult to maintain activity when developing them as immobilized soft Lewis acids ${ }^{25,26}$.

In recent years, considering the goal of atom efficiency and the scarcity of platinum resources, highactivity and low-cost platinum catalysts that contain highly dispersed Pt or even single-atom Pt catalysts have attracted widespread interest ${ }^{27,28}$. Moreover, a special strong metal-support interaction between $\mathrm{Pt}$ and $\mathrm{CeO}_{2}$ was discovered and studied in-depth, revealing that the trapping of platinum on the $\mathrm{CeO}_{2}$ surface can facilitate and sustain atomic dispersion ${ }^{29-31}$. Because of the particular properties of supported Pt in current applications, We infer that it is significant to performing research and development on supported Pt catalysts acting as soft Lewis acids.

Sustainable production of $\mathrm{C} 4$ chemicals is significant in industry ${ }^{32}$. During the series of catalytic reactions for $\mathrm{C} 4$ compounds, there are still several intermediate byproducts, such as but-3-ene-1,2-diyl diacetate (3,4-DABE) (Fig. 1a). 3,4-DABE is an isomer of but-2-ene-1,4-diyl diacetate (1,4-DABE), which is an important intermediate for the synthesis of tetrahydrofuran (THF). THF is produced million tons/year for polyesters and polyethers and several thousand tons/year of 3,4-DABE is wasted. The sustainable transformation of 3,4-DABE into 1,4-DABE will be valuable in industry and environmental protection and will be conducive to moving toward a low-carbon society.

In previous reports, several kinds of metal complex catalysts were developed for this reaction via the pallyl intermediate ${ }^{33,34}$ or soft Lewis acid mechanism ${ }^{35,36}$ (Fig. 1b). Also, only low catalytic activity was obtained when testing hard Lewis acid catalysts like montmorillonite and ZSM-5, hence, we focus on developing efficient soft Lewis acid catalysts and thus choose the isomerization of 3,4-DABE as a model reaction.

In this research, for the first time, we report that $\mathrm{Pt} / \mathrm{CeO}_{2}$ with residual chloride can act as soft Lewis acids and can facilitate the efficient isomerization of allylic esters (Fig. 1C). Interestingly, the active species in this reaction are demonstrated as highly dispersed $\mathrm{Pt}$ clusters consisting of $\mathrm{Pt}-\mathrm{Cl}$ and $\mathrm{Pt}-\mathrm{O}$ bonds. Supported Pt catalysts with soft Lewis acid functionality were successfully developed, and the residual chloride anion enhanced the Lewis acidity of the Pt metal center. This should be the first example of the application of supported Pt soft Lewis acid catalysts. Also, this is the first use of supported noble catalysts in the isomerization of allylic esters. The active catalyst can be prepared via a simple impregnation method without complex fabrication steps. The reaction can be realized under solvent-free conditions, and the TON of the catalyst reaches 5400 . The unique role of $\mathrm{Pt}-\mathrm{Cl}$ bonds in the isomerization reaction was clearly explained by the results of the reaction and density functional theory (DFT) calculations. Furthermore, based on the success of this study, our findings introduce a new 
approach for the valuable reaction of unsaturated compounds over high-performance supported Pt soft Lewis acid catalysts and provide a strategy to adjust the acidity of supported metal Lewis acid catalysts.

\section{Results}

Isomerization of 3,4-DABE. The direct transformation of 3,4-DABE to 1,4-DABE was investigated as a benchmark reaction for the isomerization of allylic esters using various heterogeneous catalysts. The equilibrium between $3,4-\mathrm{DABE}$ and 1,4-DABE was determined to be $37 / 63^{33}$, as shown in Fig. 2a. The distillation separation of 3,4- and 1,4-DABE is established in the industry. Catalyst screening was carried out with the metal oxide-supported Pd, Ir, Au, Pt catalysts, which may act as soft Lewis acids and facilitate the reaction based on the soft Lewis acid mechanism, according to the reported reaction with the Pd complex ${ }^{36}$ and Au complex catalysts ${ }^{35}$, where the highest TON is 33. To develop excellent active catalysts for the catalytic isomerization of allylic esters, we mainly chose $\mathrm{ZrO}_{2}$ and $\mathrm{CeO}_{2}$ as supports, which may promote the high dispersion of noble metal atoms on the surface, owing to the strong interaction ${ }^{37,38}$. Among the discussed supported noble metal catalysts, $\mathrm{Au} / \mathrm{ZrO}_{2}$ and $\mathrm{Pt} / \mathrm{CeO}_{2}$ afforded (2) in $11 \%$ and $52 \%$ yields, respectively (Supplementary Table 1 ). A high TON (5400) was also detected at the reaction scale of $10 \mathrm{mmol}$. With the optimized $1 \mathrm{wt} \% \mathrm{Pt} / \mathrm{CeO}_{2}$, the isomerization reaction reached equilibrium after $30 \mathrm{~min}$ and obtained a turnover frequency (TOF) of $2120 \mathrm{~h}^{-1}$ with a catalyst amount of $0.05 \mathrm{~mol} \%$ (Supplementary Figure 1). $\mathrm{Pt} / \mathrm{CeO}_{2}$ catalysts with Pt loadings less than $3 \mathrm{wt} \%$ showed high activity (Supplementary Table 2), which is probably related to the atomically dispersed Pt species that was only achieved with $\mathrm{Pt}$ loadings less than $3 \mathrm{wt} \%^{39}$. $\mathrm{Pt} / \mathrm{CeO}_{2}$ also exhibited better reusability than the other catalysts after reacting 3 times (Supplementary Figure 2). The optimized catalyst in this research is two orders of magnitude more active than previous catalysts (Fig. 2b).

The use of $\mathrm{H}_{2} \mathrm{PtCl}_{6} \cdot 6 \mathrm{H}_{2} \mathrm{O}$ as a precursor through the simple impregnation method could promote the creation of stable oxidized Pt species, such as $\mathrm{PtO}_{x} \mathrm{Cl}_{y}{ }^{40}$ and $\mathrm{Pt}(\mathrm{OH})_{x} \mathrm{Cl}_{y}{ }^{41}$. Many reports on residual chloride in Pt catalysts revealed its poisoning effect on the catalytic activity ${ }^{40,42}$. Moreover, the promoting effect of the residual chloride was also investigated in a few cases ${ }^{43}$. To remove the influence of the residual chloride, we also examined $\mathrm{Pt} / \mathrm{CeO}_{2}$ prepared by $\mathrm{Cl}$-free precursors, such as $\mathrm{Pt}(\mathrm{acac})_{2}$ and $\mathrm{Pt}\left(\mathrm{NH}_{3}\right)_{4}\left(\mathrm{NO}_{3}\right)_{2}$ (Table 1). The existence of chloride was confirmed by $X$-ray photoelectron spectroscopy (XPS) spectra (Fig. 3a). Cl-free Pt/ $\mathrm{CeO}_{2}$ showed no catalytic activities (Table 1, entries 2 and 3). In contrast, $\mathrm{Pt} / \mathrm{CeO}_{2}$ prepared from $\mathrm{H}_{2} \mathrm{PtCl}_{6} \cdot 6 \mathrm{H}_{2} \mathrm{O}$ and $\mathrm{HCl}$-treated catalysts exhibited high catalytic activity, affording 1,4-DABE in approximately $60 \%$ yield (Table 1 , entries 1,4 , and 5 ). The same effect was observed with the $\mathrm{Pt} / \mathrm{CeO}_{2}$-containing bromide anion. The reaction with $\mathrm{CeO}_{2}$ treated by $\mathrm{HCl}$ was also investigated (Table 1, entry 6 ), and no yield for the target compounds was detected. Considering these results, the chloride anion enhanced the Lewis acidity of the Pt metal center, which is essential for the catalytic activity in this reaction. 
Characterization of the Catalysts. High-angle annular dark-field scanning transmission electron microscopy (HAADF-STEM) coupled with energy-dispersive X-ray spectroscopy (EDS) mapping was used to determine the presence and size of $\mathrm{Pt}$ species on the prepared $\mathrm{Pt} / \mathrm{CeO}_{2}$ catalysts. The generation of $\mathrm{Pt}$ particles was not observed, which might be due to the high dispersion of Pt or the high atomic weight of Ce in the support. ${ }^{37}$ Notably, the EDS mapping of Pt confirmed the high dispersity (Supplementary Figure 3). The existence and fine dispersion of chlorine atoms could also be detected from the EDS mapping of $\mathrm{Cl}$.

To analyze the chemical state of the supported Pt species, the XPS spectra of the prepared catalysts were measured (Fig. 3). The quantification of the detected peaks and the spectra of $\mathrm{Ce} 3 \mathrm{~d}$ regions are presented in the Supporting Information (Supplementary Table 4 and Figure 4). In the $\mathrm{Cl} 2 p$ spectra shown in Fig. 3a, two peaks at $198.3 \mathrm{eV}$ and $200 \mathrm{eV}$ with a spin-orbit separation of $2 \mathrm{eV}$ corresponding to $2 \mathrm{p}_{1 / 2}$ and $2 \mathrm{p}_{2 / 3}$ were observed for $\mathrm{Pt} / \mathrm{CeO}_{2} \mathrm{Cl}, \mathrm{Pt} / \mathrm{CeO}_{2} \_\mathrm{A} \_\mathrm{HCl}$, and $\mathrm{Pt} / \mathrm{CeO}_{2} \_\mathrm{N} \_\mathrm{HCl}$. The results reveal the existence of residual chloride ions in the catalysts prepared by $\mathrm{H}_{2} \mathrm{PtCl}_{6} \cdot 6 \mathrm{H}_{2} \mathrm{O}$ and $\mathrm{Cl}$-free catalysts with $\mathrm{HCl}$ posttreatment. According to the reaction results, the crucial positive effect of chloride in $\mathrm{Pt} / \mathrm{CeO}_{2}$ catalysts was shown.

XPS spectra in the $\mathrm{Pt} 4 \mathrm{f}$ regions of $\mathrm{Pt} / \mathrm{CeO}_{2}$ prepared by various precursors and $\mathrm{Cl}$-free catalysts with $\mathrm{HCl}$ posttreatment were collected and analyzed by peak deconvolution (Fig. 3b). From the spectra, Pt species on the surface of $\mathrm{CeO}_{2}$ were primarily in the $\mathrm{Pt}^{2+}$ oxidation state $\left(72.7 \mathrm{eV}, \mathrm{Pt} 4 \mathrm{f}_{7 / 2}, \mathrm{Pt}(\mathrm{OH})_{2}\right.$, yellow curves) with a component from $\mathrm{Pt}^{4+}\left(74.1 \mathrm{eV}, \mathrm{Pt}_{4 / 2}, \mathrm{PtO}_{2}\right.$, blue curves) ${ }^{44}$. The invisible Pt nanoparticles in the HAADF-STEM image and the dominant $\mathrm{Pt}^{2+}$ oxidation state also support that most of the $\mathrm{Pt}$ atoms may be trapped and strongly bound on the $\mathrm{CeO}_{2}(111)$ facet by achieving 4 -fold coordination ${ }^{31,45}$. For the catalysts containing chloride ions, the $\mathrm{Pt}^{4+}(\mathrm{Cl})$ component $\left(74.8 \mathrm{eV}, \mathrm{Pt}_{4} \mathrm{f}_{7 / 2}\right.$, red curves) was noticed, considered as the $\mathrm{Pt}$ species with $\mathrm{Pt}-\mathrm{Cl}$ bonds ${ }^{40}$. After $\mathrm{HCl}$ treatment, peaks attributed to $\mathrm{Pt}^{4+}(\mathrm{Cl})$ emerged. They appeared simultaneously with peaks for $\mathrm{Cl} 2 \mathrm{p}\left(198.3 \mathrm{eV}, \mathrm{Cl} 2 \mathrm{p}_{3 / 2}\right)$. The ratio of $\mathrm{Cl} / \mathrm{Pt}$ was roughly consistent with the ratio of $\mathrm{Pt}^{4+}(\mathrm{Cl}) / \mathrm{Pt}$ among the measured catalysts, supporting the assignment of the peak at $74.8 \mathrm{eV}\left(\mathrm{Pt}_{4 \mathrm{f}_{7 / 2}}\right)$ as $\mathrm{Pt}^{4+}(\mathrm{Cl})$ (Table S2). Consequently, $\mathrm{Pt} / \mathrm{CeO}_{2}$ prepared from $\mathrm{H}_{2} \mathrm{PtCl}_{6} \cdot 6 \mathrm{H}_{2} \mathrm{O}$ and $\mathrm{HCl}$-treated catalysts contains residual chloride ions, exhibiting high catalytic activity (Fig. 3c).

$\mathrm{Pt} \mathrm{L}_{\| 1}$-edge $\mathrm{X}$-ray absorption near edge structure (XANES) spectra of $\mathrm{Pt}$ foil and $\mathrm{Pt} / \mathrm{CeO}_{2}$ prepared by various precursors in an air atmosphere are shown in Fig. 4a. The characteristic peak, the white line, at $11568 \mathrm{eV}$ was observed for the catalysts, which indicates that the Pt in the catalysts had high oxidation states $^{46}$. The intensity of the white line for $\mathrm{Pt} / \mathrm{CeO}_{2} \mathrm{Cl}$ was higher than those for $\mathrm{Pt} / \mathrm{CeO}_{2} \mathrm{~A}$ and 
$\mathrm{Pt} / \mathrm{CeO}_{2} \mathrm{~N}$. After $\mathrm{HCl}$ treatment, increased intensities of the white lines were observed in the spectra of $\mathrm{Pt} / \mathrm{CeO}_{2} \_\mathrm{A} \_\mathrm{HCl}$ and $\mathrm{Pt} / \mathrm{CeO}_{2} \_\mathrm{A} \_\mathrm{HCl}$, revealing the increased oxidation state related to the generation of chloride (Fig. 4c).

In phase-uncorrected radial structure functions (RSFs) for $\mathrm{Pt} / \mathrm{CeO}_{2}$ prepared by various precursors (Fig. $4 b)$, two peaks were mainly observed at approximately $1.65 \AA$ and $1.95 \AA$ in $\mathrm{Pt} / \mathrm{CeO}_{2} \mathrm{Cl}$. Compared with the peaks of the reference sample of $\mathrm{Pt}$ foil, $\mathrm{PtO}_{2}$, and $\mathrm{K}_{2} \mathrm{PtCl}_{6}$, the peak at approximately $1.65 \AA$ were attributed to $\mathrm{Pt}-\mathrm{O}$ coordination, and the peak at approximately $1.95 \AA$ was attributed to $\mathrm{Pt}-\mathrm{Cl}$ coordination. The weak peak intensities at $2.60 \AA$ and $2.85 \AA$, corresponding to the Pt-Pt coordination distance in $\mathrm{Pt}$ foil and the $\mathrm{Pt}-\mathrm{O}-\mathrm{Pt}$ coordination distance in $\mathrm{PtO}_{2}$, respectively, were much smaller than those of the reference compounds, supporting the high dispersion of Pt species and the formation of Pt nanoclusters or even atomic Pt species. This finding was also consistent with the results of HAADF-TEM. In the spectra of $\mathrm{Pt} / \mathrm{CeO}_{2} \mathrm{~A}$ and $\mathrm{Pt} / \mathrm{CeO}_{2} \mathrm{~N}$, peaks at approximately $1.65 \AA$ and $2.85 \AA$ were observed, and almost no peaks at approximately $1.95 \AA$ were found, revealing the generation of $\mathrm{PtO}_{x}$ species. After $\mathrm{HCl}$ treatment, in the spectra of $\mathrm{Pt} / \mathrm{CeO}_{2}-\mathrm{A} \_\mathrm{HCl}$ and $\mathrm{Pt} / \mathrm{CeO}_{2}-\mathrm{N} \_\mathrm{HCl}$, peaks at approximately $1.65 \AA$ and $1.95 \AA$ were observed (Fig. 4d). No obvious peaks were found around the distances of other bonds. Considering the reaction results and the XPS spectra, the active species were proven to contain both Pt-O and $\mathrm{Pt}-\mathrm{Cl}$ that were highly dispersed. Additionally, the $k^{3}$-weighted $\mathrm{Pt} \mathrm{L}_{\| 1}$-edge extended $\mathrm{X}$-ray absorption fine structure (EXAFS) oscillation patterns of $\mathrm{Pt} / \mathrm{CeO}_{2}-\mathrm{Cl}, \mathrm{Pt} / \mathrm{CeO}_{2}-\mathrm{A} \_\mathrm{HCl}$, and $\mathrm{Pt} / \mathrm{CeO}_{2} \_\mathrm{N} \_\mathrm{HCl}$ were compared with those of $\mathrm{PtO}_{2}, \mathrm{Na}_{2} \mathrm{Pt}(\mathrm{OH})_{6}$ and $\mathrm{K}_{2} \mathrm{PtCl}_{6}$ (Supplementary Figure 5). The oscillation patterns of $\mathrm{Pt} / \mathrm{CeO}_{2} \mathrm{Cl}, \mathrm{Pt} / \mathrm{CeO}_{2}-\mathrm{A} \_\mathrm{HCl}$, and $\mathrm{Pt} / \mathrm{CeO}_{2} \mathrm{~N}_{-} \mathrm{HCl}$ were between those of $\mathrm{K}_{2} \mathrm{PtCl}_{6}$ and $\mathrm{PtO}_{2}$, supporting the existence of $\mathrm{Pt}-\mathrm{O}$ coordination and $\mathrm{Pt}-\mathrm{Cl}$ coordination in the active catalysts.

Furthermore, the structural parameters of the $\mathrm{Pt} / \mathrm{CeO}_{2}$ catalysts discussed above were obtained by EXAFS curve-fitting analysis (Supplementary Table 5). The coordination numbers (CNs) of Pt- 0 for the first shell of the $\mathrm{Pt} / \mathrm{CeO}_{2}$ catalyst prepared from three kinds of precursors were approximately between 3 and 4. For $\mathrm{Pt} / \mathrm{CeO}_{2} \mathrm{Cl}$, the $\mathrm{CN}$ value of $\mathrm{Pt}-\mathrm{Cl}$ was $1.49 \pm 0.78$. After $\mathrm{HCl}$ treatment, the $\mathrm{CN}$ values of $\mathrm{Pt}-\mathrm{Cl}$ were approximately $1.76 \pm 1.03\left(\mathrm{Pt} / \mathrm{CeO}_{2} \_\mathrm{A} \_\mathrm{HCl}\right)$ and $1.79 \pm 0.27\left(\mathrm{Pt} / \mathrm{CeO}_{2} \_\mathrm{N} \_\mathrm{HCl}\right)$. A similar $\mathrm{CN}$ ratio $\left(\mathrm{x} / \mathrm{y}, \mathrm{PtO}_{x} \mathrm{Cl}_{y}\right)$ between $\mathrm{Pt}-\mathrm{O}$ and $\mathrm{Pt}-\mathrm{Cl}$ of approximately 2.4 was found for $\mathrm{Pt} / \mathrm{CeO}_{2} \mathrm{Cl}$ and $\mathrm{Pt} / \mathrm{CeO}_{2} \_\mathrm{A} \_\mathrm{HCl}$. For $\mathrm{Pt} / \mathrm{CeO}_{2}{ }_{-} \mathrm{N} \_\mathrm{HCl}$, the ratio was approximately 1.2 . This result also correlated with the observation of $\mathrm{Pt}(\mathrm{OH})_{x} \mathrm{Cl}_{y}$ and $\mathrm{PtO}_{x} \mathrm{Cl}_{y}$.

For further investigation, $\mathrm{Pt} \mathrm{L}_{\| \mid}$-edge XANES spectra of $\mathrm{Pt}$ catalysts supported by various metal oxides were measured in an air atmosphere. Estimating the intensities of the white lines, the oxidation states of Pt species supported on other metal oxides were lower than those on $\mathrm{CeO}_{2}$ (Supplementary Figure 6). Pt$\mathrm{O}$ and $\mathrm{Pt}-\mathrm{Cl}$ bonds were also detected in the phase-uncorrected RSFs of these catalysts, and a relatively low intensity was observed for the catalysts with low catalytic activity. The oxidation state of Pt species in the catalysts was analyzed by the edge energy of Pt $\mathrm{L}_{\text {I }}$-edge XANES spectra (Supplementary Figure 7). 
The oxidation states of $\mathrm{Pt}$ in $\mathrm{Pt} / \mathrm{CeO}_{2} \mathrm{Cl}$ were nearly $4+$ and higher compared with those of $\mathrm{Pt} / \mathrm{Al}_{2} \mathrm{O}_{3}{ }_{-} \mathrm{Cl}$. These results suggest that a higher oxidation state of Pt shows higher catalytic activity.

Moreover, the structural parameters of $\mathrm{Cl}$-containing Pt catalysts supported by other metal oxides were also estimated by curve-fitting analysis (Supplementary Table 5). Although the $\mathrm{CN}$ value of $\mathrm{Pt}-\mathrm{Cl}$ in $\mathrm{Pt} / \mathrm{ZrO}_{2} \mathrm{Cl}$ was similar to that of $\mathrm{Pt} / \mathrm{CeO}_{2} \mathrm{Cl}$, the $\mathrm{CN}$ value of $\mathrm{Pt}-\mathrm{O}$ was much lower than that of $\mathrm{Pt} / \mathrm{CeO}_{2} \mathrm{Cl}$. Summarizing the above results, the high oxidation state, $\mathrm{CN}$ value of $\mathrm{Pt}-\mathrm{Cl}$ and dispersity were core factors affecting the catalytic activity, and $\mathrm{CeO}_{2}$ could help the Pt species on its surface maintain a high oxidation state and dispersity ${ }^{45,47}$.

Hydrogen temperature-programmed reduction $\left(\mathrm{H}_{2}\right.$-TPR) was performed to investigate the active $\mathrm{Pt}$ species (Supplementary Figure 8\&9). Active $\mathrm{Pt}$ species were mainly considered $\mathrm{Pt}(\mathrm{OH})_{x} \mathrm{Cl}_{y}$ and $\mathrm{PtO}_{x} \mathrm{Cl}_{y}$ with the reference peaks obtained ${ }^{48-50}$. This result was consistent with the result of the EXAFS spectra. The shift in the temperature may be related to the difference in the ratio of $x / y$ of the species. Based on the above experimental results, the formed $\mathrm{Pt}-\mathrm{Cl}$ bonds in $\mathrm{Pt} / \mathrm{CeO}_{2}$ catalysts play an essential role in the high catalytic activity, which should be due to the stably enhanced acidity of Pt in the presence of chloride anions. The active species on $\mathrm{CeO}_{2}$ are considered $\mathrm{Pt}(\mathrm{OH})_{x} \mathrm{Cl}_{y}$ and $\mathrm{PtO}_{x} \mathrm{Cl}_{y}$, which can be obtained from a simple impregnation method or $\mathrm{HCl}$ posttreatment. Also, because of the strong interaction between $\mathrm{Pt}$ and $\mathrm{CeO}_{2}$, Pt-Cl clusters can easily be highly dispersed and help Pt maintain a high oxidation state.

Catalytic Isomerization of Allylic Esters. The reaction mechanism of the catalytic isomerization of allylic esters could be primarily classified into the $\mathrm{p}$-allyl intermediate mechanism and the soft Lewis acid mechanism. Pentanoic acid was added to the reaction system to confirm the actual mechanism of the reaction using $\mathrm{Pt} / \mathrm{CeO}_{2}$ catalysts. Only the products of $(E)-2 \mathbf{a}$ and $(Z)-2 \mathbf{a}$ were detected after the reaction, no exchange between externally added pentanoic acid, demonstrating that the mechanism for the isomerization of allylic esters over $\mathrm{Pt} / \mathrm{CeO}_{2}$ should be a soft Lewis acid mechanism (Fig. 5).

A substrate scope investigation was carried out under the optimized reaction conditions. The prepared active $\mathrm{Pt} / \mathrm{CeO}_{2}$ catalysts also provided excellent reaction activity for the catalytic isomerization of other allylic acetates (Supplementary Figure 10) and allylic benzoates (Supplementary Figure 11). Homogeneous Pt and Pd catalysts were also examined for allylic benzoate (results listed in Supplementary Table 6). The soft Lewis acid complexes including $\mathrm{PdCl}_{2}(\mathrm{MeCN})_{2}$ afforded the product for allylic benzoate as well as $\mathrm{Pt} / \mathrm{CeO}_{2}$ although TON was low $\left(5000\right.$ for $\mathrm{Pt} / \mathrm{CeO}_{2}$ cf. 6 for $\left.\mathrm{PdCl}_{2}(\mathrm{MeCN})_{2}\right)$. It is noteworthy that $\mathrm{Pd}(0)$ and $\mathrm{Pt}(0)$ complexes, that can catalyze the reaction through a p-allyl intermediate, only gave eliminated diene due to the low nucleophilicity of benzoate. These results also supported the soft Lewis acid mechanism for $\mathrm{Pt} / \mathrm{CeO}_{2}$ catalysts.

The proposed catalytic cycle for the isomerization of allylic esters was presented, and the hexatomic ring state on the Pt catalysts was considered to be a transition state (Supplementary Figure 12). 
Result of Calculations. Since the Pt-Cl clusters supported by metal oxides were confirmed as the active species for the catalytic isomerization of allylic esters, the quantum chemical calculation was utilized to investigate the role of the charge on Pt clusters. Fig. 6 illustrates the typical reaction profile for the catalytic isomerization of allylic esters based on cationic Pt cluster model systems.

Primarily, DFT calculations on the isolated cluster model were performed with Gaussian09 to discuss the relationship between the activation energies and the charge of the Pt cluster. The calculation results of the reaction process based on the cluster model agreed with the proposed Lewis acid mechanism, and INI-TS1 was considered the activation energy barrier because of the major energy gap between TS1 and INI (Fig. 6a). In other words, the catalytic activities of cationic clusters are much better than those of neutral clusters. The detailed results are not shown here. The change in energy of the transition state corresponds to a reversible reaction.

Afterward, a slab model was built with single-atom tetravalent Pt species containing $\mathrm{Pt}-\mathrm{Cl}$ bonds and $\mathrm{Pt}-\mathrm{O}$ bonds on $\mathrm{CeO}_{2}(111)$ surfaces to further simulate the actual reaction path (Fig. 6b), such as $\mathrm{PtOCl}_{2} / \mathrm{CeO}_{2}, \mathrm{PtCl}_{4} / \mathrm{CeO}_{2}$, and $\mathrm{PtO}_{2} / \mathrm{CeO}_{2}$ with VASP code. $\mathrm{Cl}-\mathrm{Ce}$ bonding was observed in the optimized model of $\mathrm{PtCl}_{4} / \mathrm{CeO}_{2}$, where the $\mathrm{Cl}-\mathrm{Ce}$ group can act as a Lewis acid and thus likely enhance the acidity of the Pt metal center in the Lewis acid-assisted approach ${ }^{51,52}$. The energy of each state for the whole process was optimized, and the diagram of the results shows that the activation energy barrier and adsorption-desorption energy were small enough to facilitate this reaction when using $\mathrm{Pt} / \mathrm{CeO}_{2}$ catalysts containing $\mathrm{Pt}-\mathrm{Cl}$ bonds (Fig. 6c). Additionally, the calculation of the reaction over $\mathrm{PtO}_{2} / \mathrm{CeO}_{2}$ was performed, and the result reveals that the adsorption of 3,4-DABE should occur via di- $\sigma$ (Pt-O) bonding between the $\mathrm{C}=\mathrm{C}$ and $\mathrm{Pt}-\mathrm{O}$ instead of the p-bond (Fig. $6 \mathrm{~d}$ ). Because of the large activation energy barrier $(1.40 \mathrm{eV})$ and high desorption energy $(2.14 \mathrm{eV}), \mathrm{PtO}_{2} / \mathrm{CeO}_{2}$ was proven to show low activity for this kind of reaction (see the Supporting Information for computational details). The results of DFT calculations are basically consistent with the results of the reaction and characterization experiments. This finding should promote the understanding of the effects of the fine structure or composition of supported platinum catalysts on catalytic organic reactions based on olefin compounds.

\section{Conclusion}

In conclusion, the effective isomerization of allylic esters was realized under solvent-free conditions over metal oxide-supported Pt catalysts, which can act as soft Lewis acids. Stable reusability, a high TON (up to 5400), and a wide substrate scope are confirmed with optimized Pt catalysts. With the aid of structural characterizations, the active species on $\mathrm{CeO}_{2}$ were detected as Pt oxide clusters containing $\mathrm{Pt}-\mathrm{Cl}$ bonds, such as $\mathrm{PtO}_{x} \mathrm{Cl}_{y}$. The reaction process with the prepared Pt catalysts was proven to be based on the soft Lewis acid mechanism, as revealed by experiments and DFT calculations. The analysis results show that $\mathrm{Pt}-\mathrm{Cl}$ bonds, the high oxidation state of $\mathrm{Pt}$, and the strong interaction between the support and Pt play crucial roles in the high activity of supported Pt catalysts in this reaction. This research provides valuable examples of supported Pt soft Lewis acids that can directly catalyze the isomerization of allylic esters 
under simple conditions. Moreover, the essential role of the residual chloride anion and its enhancement effect on the Lewis acidity of the Pt metal center and thus the high catalytic activity should also be significant for heterogeneous catalyst design in the future.

\section{Method}

Materials. Chloroplatinic acid hexahydrate $\left(\mathrm{H}_{2} \mathrm{PtCl}_{6} \cdot 6 \mathrm{H}_{2} \mathrm{O}\right)$ was purchased from Furuya Metal Co., Ltd. Palladium nitrate $\left(\mathrm{Pd}\left(\mathrm{NO}_{3}\right)_{2}\right)$ and hydrogen tetrachloroaurate tetrahydrate $\left(\mathrm{HAuCl}_{4} \bullet 4 \mathrm{H}_{2} \mathrm{O}\right)$ were purchased from Tanaka Precious Metal Co., Ltd. Platinum acetylacetonate (Pt(acac) $\left.)_{2}\right)$, tetraammineplatinum(II) nitrate $\left(\mathrm{Pt}\left(\mathrm{NH}_{3}\right)_{4}\left(\mathrm{NO}_{3}\right)_{2}\right)$, and hydrogen hexachloroiridate(IV) n-hydrate $\left(\mathrm{H}_{2} \mathrm{IrCl}_{6} \cdot \mathrm{nH}_{2} \mathrm{O}\right)$ were purchased from Wako Pure Chemical Industries. $\mathrm{CeO}_{2}\left(\mathrm{JRC}-\mathrm{CEO}-3,81 \mathrm{~m}^{2} / \mathrm{g}\right)$ and $\mathrm{ZrO}_{2}$ (JRC-ZRO-4, $30 \mathrm{~m}^{2} / \mathrm{g}$ ) were Japan reference catalysts supplied by the Catalysts Society of Japan. $\mathrm{Al}_{2} \mathrm{O}_{3}$ with a specific surface area of $179 \mathrm{~m}^{2} / \mathrm{g}$ was purchased from Mizusawa Industrial Chemicals, Ltd. $\mathrm{MgO}$ with a specific surface area of $8 \mathrm{~m}^{2} / \mathrm{g}$ was purchased from Ube Industries, Ltd. $\mathrm{TiO}_{2}$ (PC-101) was purchased from Titan Kogyo, Ltd. 3,4-DABE was purchased from Wako Pure Chemical Industries and used as received. All chemicals were used without further purification.

Catalyst Preparation. $\mathrm{Pt} / \mathrm{CeO}_{2}, \mathrm{Pt} / \mathrm{ZrO}_{2}, \mathrm{Pt} / \mathrm{Al}_{2} \mathrm{O}_{3}, \mathrm{Pt} / \mathrm{TiO}_{2}$, and $\mathrm{Pt} / \mathrm{MgO}$ catalysts with a Pt loading of 1 wt\% were prepared by the impregnation method. $\mathrm{H}_{2} \mathrm{PtCl}_{6}$ aqueous solution (Pt: $19.75 \mathrm{~g} / \mathrm{L} ; 511 \mu \mathrm{L}$ ) was diluted in $1.5 \mathrm{~mL}$ distilled water. A metal oxide support $(1.0 \mathrm{~g})$ was added to the aqueous solution and stirred at room temperature for $30 \mathrm{~min}$. After the impregnation process was complete, the catalysts were dried via a vacuum freeze method overnight. Then, the catalysts were calcined in a furnace at $300{ }^{\circ} \mathrm{C}$ for $4 \mathrm{~h}$. $\mathrm{Pt} / \mathrm{CeO}_{2} \mathrm{Cl}$-free catalysts were also prepared by the impregnation method from $\mathrm{Pt}(\mathrm{acac})_{2}$ and $\mathrm{Pt}\left(\mathrm{NH}_{3}\right)_{4}\left(\mathrm{NO}_{3}\right)_{2}$ and were named $\mathrm{Pt} / \mathrm{CeO}_{2} \mathrm{~A}$ and $\mathrm{Pt} / \mathrm{CeO}_{2} \_\mathrm{N}$, respectively. Pt(acac) 2 (20.4 mg) was dissolved in $2 \mathrm{~mL}$ dehydrated toluene, and the following procedures were as described above. $\mathrm{Pt}\left(\mathrm{NH}_{3}\right)_{4}\left(\mathrm{NO}_{3}\right)_{2}(20.1 \mathrm{mg})$ was dissolved in $2 \mathrm{~mL} 0.5 \mathrm{M} \mathrm{HNO}_{3}$. The following procedures were the same as described above.

Ir $/ \mathrm{CeO}_{2}$ catalysts were prepared by the impregnation method. $\mathrm{H}_{2} \mathrm{IrCl}_{6} \cdot \mathrm{nH}_{2} \mathrm{O}$ (Ir: $36.5 \mathrm{wt} \% ; 27.7 \mathrm{mg}$ ) was diluted in $1.5 \mathrm{~mL}$ distilled water. The following procedures were the same as described above.

$\mathrm{Pd} / \mathrm{CeO}_{2}$ and $\mathrm{Pd} / \mathrm{ZrO}_{2}$ catalysts were prepared by the impregnation method. $\mathrm{Pd}\left(\mathrm{NO}_{3}\right)_{2}$ aqueous solution (Pd: $200 \mathrm{~g} / \mathrm{L}$ ) was diluted in a small amount of water. $\mathrm{ZrO}_{2}$ or $\mathrm{CeO}_{2}(1.0 \mathrm{~g})$ was added to the aqueous solution and stirred at RT for $30 \mathrm{~min}$. After the impregnation process was complete, $\mathrm{H}_{2} \mathrm{O}$ was removed by freeze-drying. The obtained catalysts were calcined at $550{ }^{\circ} \mathrm{C}$ for $4 \mathrm{~h}$ and then reduced in a flow of pure $\mathrm{H}_{2}(20 \mathrm{~mL} / \mathrm{min})$ at $200{ }^{\circ} \mathrm{C}$ for $2 \mathrm{~h}$ to obtain $\mathrm{Pd} / \mathrm{CeO}_{2}$ or $\mathrm{Pd} / \mathrm{ZrO}_{2}$.

$\mathrm{Au} / \mathrm{ZrO}_{2}$ was prepared by homogeneous deposition-precipitation (HDP). $\mathrm{ZrO}_{2}(1.0 \mathrm{~g})$ was added to an aqueous solution $(100 \mathrm{~mL})$ of $\mathrm{HAuCl}_{4} \bullet 4 \mathrm{H}_{2} \mathrm{O}(21.1 \mathrm{mg})$ and urea $(7.6 \mathrm{~g})$. The mixture was stirred at $90{ }^{\circ} \mathrm{C}$ 
for $10 \mathrm{~h}$. The solid was collected by filtration, washed with water, and dried in air at $70^{\circ} \mathrm{C}$ overnight. The solid was calcined in air at $300{ }^{\circ} \mathrm{C}$ for $4 \mathrm{~h}$ and used for catalytic reactions without further treatment.

$\mathrm{HCl}$ treatment was performed with $\mathrm{Pt} / \mathrm{CeO}_{2}$ catalysts prepared by $\mathrm{Cl}$-free precursors. Treated catalysts were named $\mathrm{Pt} / \mathrm{CeO}_{2}-\mathrm{A} \_\mathrm{HCl}$ and $\mathrm{Pt} / \mathrm{CeO}_{2} \_\mathrm{N} \_\mathrm{HCl}$. The prepared catalysts $(100 \mathrm{mg})$ were added into a 0.1 $\mathrm{M} \mathrm{HCl}$ solution $(1.5 \mathrm{~mL})$ and stirred at $90^{\circ} \mathrm{C}$ for $6 \mathrm{~h}$. The solid was filtered and vacuum freeze-dried for 4 h. The obtained catalysts were calcined again at $300^{\circ} \mathrm{C}$ for $1 \mathrm{~h}$.

Characterization. HAADF-STEM images were acquired with a JEOL JEM-ARM200F operated at $200 \mathrm{kV}$. The loading amount of $\mathrm{Pt}$ in the prepared catalysts was determined by microwave plasma-atomic emission spectrometry (MP-AES) via an Agilent 4100 MP-AES instrument. Powder X-ray diffraction (XRD) was performed using a Rigaku MiniFlex600 instrument equipped with a $\mathrm{Cu}_{\mathrm{a}}$ radiation source. The nature of the surface species was analyzed by XPS using a Shimadzu AXIS-165 spectrometer equipped with $\mathrm{Al} \mathrm{K} \mathrm{K}_{\mathrm{a}}$ radiation at a pressure lower than $10^{-6} \mathrm{~Pa}$. The obtained binding energies were calibrated to the C1s peak at $284.8 \mathrm{eV}$. XPS spectra were further analyzed using XPS PEAK41 software. The local structures of Pt species were analyzed by $\mathrm{Pt} \mathrm{L}_{\| \mid}$-edge XAFS spectra collected the BL14B2 beamline of Spring-8 (Hyogo, Japan) ${ }^{53,54}$. XAFS measurement experiments were conducted in fluorescence mode. The specific spectral analysis was performed using the XAFS analysis software Athena and REX2000. Temperature-programmed reduction of $\mathrm{H}_{2}\left(\mathrm{H}_{2}\right.$-TPR) was analyzed using a BELCAT instrument equipped with a thermal conductivity detector (TCD).

Conversions and yields of the compounds discussed were analyzed by gas chromatography (GC) using an Agilent GC 6850 Series II instrument equipped with a flame ionization detector (FID) and a J\&W HP-1 column using tridecane as an internal standard. ${ }^{1} \mathrm{H}$ and ${ }^{13} \mathrm{C}$ NMR spectra were analyzed on a JEOL JNMECS400 or JEOL JNM-ECA600 spectrometer.

General Procedure for the Catalytic Reactions. A glass tube was charged with $1 \mathrm{wt} \%$ supported Pt catalysts (Pt $0.01 \mathrm{~mol} \%, 2.0 \mathrm{mg}$; Pt $0.05 \mathrm{~mol} \%, 9.8 \mathrm{mg}$; Pt $0.15 \mathrm{~mol} \%, 29.3 \mathrm{mg}$ ), but-3-ene-1,2-diyl diacetate $(1 \mathrm{mmol})$ and a magnetic stirring bar. The reaction mixture was stirred at $150{ }^{\circ} \mathrm{C}$ under an $\mathrm{N}_{2}$ or air atmosphere (1 atm). After the reaction, the mixture was filtered, and the filtrate was analyzed by GC using tridecane as an internal standard. In the large-scale reaction of $10 \mathrm{mmol}, 19.5 \mathrm{mg}$ (Pt $0.01 \mathrm{~mol} \%)$ $\mathrm{Pt} / \mathrm{CeO}_{2}$, but-3-ene-1,2-diyl diacetate $(10 \mathrm{mmol})$, and a magnetic stirring bar were added to the glass tube, and the catalytic activity was tested through the same method mentioned above. In a recycling experiment, a glass tube was charged with $1 \mathrm{wt} \% \mathrm{Pt} / \mathrm{CeO}_{2}$ catalysts $(0.15 \mathrm{~mol} \%, 29.3 \mathrm{mg})$, but-3-ene-1,2diyl diacetate $(1 \mathrm{mmol})$ and a magnetic stirring bar. The catalytic activity was tested through the same method mentioned above. The glass tube was cooled in an ice bath for approximately 20 min after reacting for $2 \mathrm{~h}$. The Pt catalysts were washed with $\mathrm{Et}_{2} \mathrm{O}$, collected by centrifugation, and dried under vacuum conditions. Then, the obtained Pt catalysts were used for the next reaction. 
Computational Methods. DFT calculations for the model cluster systems were carried out using Gaussian $09^{55}$. For the model clusters, a $6-31+G(d)$ basis set for $\mathrm{C}, \mathrm{O}$, and $\mathrm{H}$ atoms and LANL2DZ for Pt atoms were used, and hybrid DFT (PBE0 functional) was applied. First-principles calculations using DFT for the structures and electronic states of the slab models were carried out with the Vienna Ab initio Simulation Package (VASP) ${ }^{56,57}$. The projector-augmented-wave (PAW) ${ }^{58}$ method was utilized for the calculation of the ionic core electrons. The Perdew-Burke-Ernzerhof (PBE) ${ }^{59}$ functional with a cutoff energy of $400 \mathrm{eV}$ was set for the determination of the exchange-correlation term. To confirm the possible behavior of electrons in the supported Pt catalysts, the DFT $+U$ method $(U(C e, 4 f)=5.0 \mathrm{eV})$ was used ${ }^{60}$.

\section{Data availability}

The data that support the findings of this study are available from the corresponding authors on reasonable request.

\section{References}

(1) Bing, Y.; Liu, H.; Zhang, L.; Ghosh, D.; Zhang, J. Nanostructured Pt-Alloy Electrocatalysts for PEM Fuel Cell Oxygen Reduction Reaction. Chem. Soc. Rev. 39, 2184-2202 (2010).

(2) Debe, M. K. Electrocatalyst Approaches and Challenges for Automotive Fuel Cells. Nature 486, 43-51 (2012).

(3) Nibbelke, R. H.; Nievergeld, A. J. L.; Hoebink, J. H. B. J.; Marin, G. B. Development of a Transient Kinetic Model for the $\mathrm{CO}$ Oxidation by $\mathrm{O}_{2}$ over a Pt/Rh/CeO2/ $/-\mathrm{Al}_{2} \mathrm{O}_{3}$ Three-Way Catalyst. Appl. Catal. B Environ. 19, 245-259 (1998).

(4) Tanaka, H.; Taniguchi, M.; Uenishi, M.; Kajita, N.; Tan, I.; Nishihata, Y.; Mizuki, J.; Narita, K.; Kimura, M.; Kaneko, K. Self-Regenerating Rh- and Pt-Based Perovskite Catalysts for Automotive-Emissions Control. Angew. Chem. Int. Ed. 45, 5998-6002 (2006).

(5) Ding, K.; Gulec, A.; Johnson, A. M.; Schweitzer, N. M.; Stucky, G. D.; Marks, L. D.; Stair, P. C. Identification of Active Sites in CO Oxidation and Water-Gas Shift over Supported Pt Catalysts. Science 350, 189-192 (2015).

(6) Kuwahara, Y.; Yoshimura, Y.; Haematsu, K.; Yamashita, H. Mild Deoxygenation of Sulfoxides over Plasmonic Molybdenum Oxide Hybrid with Dramatic Activity Enhancement under Visible Light. J. Am. Chem. Soc. 140, 9203-9210 (2018).

(7) Chen, C. B.; Chen, M. Y.; Zada, B.; Ma, Y. J.; Yan, L.; Xu, Q.; Li, W. zhi; Guo, Q. X.; Fu, Y. Effective Conversion of Biomass-Derived Ethyl Levulinate into $y$-Valerolactone over Commercial Zeolite Supported Pt Catalysts. RSC Adv. 6, 112477-112485 (2016). 
(8) Siddiki, S. M. A. H.; Touchy, A. S.; Jamil, M. A. R.; Toyao, T.; Shimizu, K. I. C -Methylation of Alcohols, Ketones, and Indoles with Methanol Using Heterogeneous Platinum Catalysts. ACS Catal. 8, 3091-3103 (2018).

(9) Hartman, J. W., Hiscox, W. C. \& Jennings, P. W. Catalytic Hydration of Alkynes with Platinum(II) Complexes. J. Org. Chem. 58, 7613-7614 (1993).

(10) Jiang, X. Bin, Minnaard, A. J., Feringa, B. L. \& De Vries, J. G. Platinum-Catalyzed Selective Hydration of Hindered Nitriles and Nitriles with Acid- or Base-Sensitive Groups. J. Org. Chem. 69, 2327-2331 (2004).

(11) Lucey, D. W. \& Atwood, J. D. Insight into the selective room-temperature platinum(II) catalytic hydration of alkynes in water. Organometallics 21, 2481-2490 (2002).

(12) Xing, X. et al. Highly Active Platinum Catalysts for Nitrile and Cyanohydrin Hydration: Catalyst Design and Ligand Screening via High-Throughput Techniques. J. Am. Chem. Soc. 140, 17782-17789 (2018).

(13) Scarso, A.; Colladon, M.; Sgarbossa, P.; Santo, C.; Michelin, R. A.; Strukul, G. Highly Active and Selective Platinum(II)-Catalyzed Isomerization of Allylbenzenes: Efficient Access to (E)-Anethole and Other Fragrances via Unusual Agostic Intermediates. Organometallics 29, 1487-1497 (2010).

(14) Bhanu Prasad, B. A., Yoshimoto, F. K. \& Sarpong, R. Pt-catalyzed pentannulations from in situ generated metallo-carbenoids utilizing propargylic esters. J. Am. Chem. Soc. 127, 12468-12469 (2005).

(15) Pearson, R. G. Absolute Electronegativity and Absolute Hardness of Lewis Acids and Bases. J. Am. Chem. Soc. 107, 6801-6806 (1985).

(16) Dapsens, P. Y., Mondelli, C. \& Pérez-Ramírez, J. Design of Lewis-acid centres in zeolitic matrices for the conversion of renewables. Chem. Soc. Rev. 44, 7025-7043 (2015).

(17) Li, Y., Li, L. \& Yu, J. Applications of Zeolites in Sustainable Chemistry. Chem 3, 928-949 (2017).

(18) Corma, A.; González-Arellano, C.; Iglesias, M.; Navarro, M. T.; Sánchez, F. Synthesis of Bifunctional AuSn Organic-Inorganic Catalysts for Acid-Free Hydroamination Reactions. Chem. Commun. 46, 6218-6220 (2008).

(19) Corma, A.; Concepción, P.; Domínguez, I.; Forné, V.; Sabater, M. J. Gold Supported on a Biopolymer (Chitosan) Catalyzes the Regioselective Hydroamination of Alkynes. J. Catal. 251, 39-47 (2007).

(20) Sahoo, M.; Parida, K. Facile Fabrication of Organic-Inorganic Hybrid Material Based on WellDispersed AuNPs on Organo-Functionalised Zn-Al-Layered Double Hydroxides for Hydroamination of 1Hexene. ChemistrySelect 3, 3092-3100 (2018). 
(21) Lee, L. C.; Zhao, Y. Room Temperature Hydroamination of Alkynes Catalyzed by Gold Clusters in Interfacially Cross-Linked Reverse Micelles. ACS Catal. 4, 688-691 (2014).

(22) Gryparis, C.; Efe, C.; Raptis, C.; Lykakis, I. N.; Stratakis, M. Cyclization of 1,6-Enynes Catalyzed by Gold Nanoparticles Supported on $\mathrm{TiO}_{2}$ : Significant Changes in Selectivity and Mechanism, as Compared to Homogeneous Au-Catalysis. Org. Lett. 14, 2956-2959 (2012).

(23) Ye, R.; Zhukhovitskiy, A. V.; Kazantsev, R. V.; Fakra, S. C.; Wickemeyer, B. B.; Toste, F. D.; Somorjai, G. A. Supported Au Nanoparticles with N-Heterocyclic Carbene Ligands as Active and Stable Heterogeneous Catalysts for Lactonization. J. Am. Chem. Soc. 140, 4144-4149 (2018).

(24) Stephan, D. W. Frustrated Lewis Pairs. J. Am. Chem. Soc. 137, 10018-10032 (2015).

(25) Cai, R.; Ye, X.; Sun, Q.; He, Q.; He, Y.; Ma, S.; Shi, X. Anchoring Triazole-Gold(I) Complex into Porous Organic Polymer to Boost the Stability and Reactivity of Gold(I) Catalyst. ACS Catal. 7, 1087-1092 (2017).

(26) Otake, K. I.; Ye, J.; Mandal, M.; Islamoglu, T.; Buru, C. T.; Hupp, J. T.; Delferro, M.; Truhlar, D. G.; Cramer, C. J.; Farha, O. K. Enhanced Activity of Heterogeneous Pd(II) Catalysts on Acid-Functionalized MetalOrganic Frameworks. ACS Catal. 9, 5383-5390 (2019).

(27) Tang, Z.; Liu, P.; Cao, H.; Bals, S.; Heeres, H. J.; Pescarmona, P. P. Pt/ZrO 2 Prepared by Atomic Trapping: An Efficient Catalyst for the Conversion of Glycerol to Lactic Acid with Concomitant Transfer Hydrogenation of Cyclohexene. ACS Catal. 9, 9953-9963 (2019).

(28) Nie, L.; Mei, D.; Xiong, H.; Peng, B.; Ren, Z.; Hernandez, X. I. P.; DeLaRiva, A.; Wang, M.; Engelhard, M. $\mathrm{H} . ;$ Kovarik, L.; et al. Activation of Surface Lattice Oxygen in Single-Atom Pt/CeO ${ }_{2}$ for Low-Temperature Co Oxidation. Science 358, 1419-1423 (2017).

(29) Daelman, N.; Capdevila-Cortada, M.; López, N. Dynamic Charge and Oxidation State of Pt/ $\mathrm{CeO}_{2}$ Single-Atom Catalysts. Nat. Mater. 18, 1215-1221 (2019).

(30) Pereira-Hernández, X. I.; DeLaRiva, A.; Muravev, V.; Kunwar, D.; Xiong, H.; Sudduth, B.; Engelhard, M.; Kovarik, L.; Hensen, E. J. M.; Wang, Y.; et al. Tuning Pt- $\mathrm{CeO}_{2}$ Interactions by High-Temperature VaporPhase Synthesis for Improved Reducibility of Lattice Oxygen. Nat. Commun. 10, 1358 (2019).

(31) Dvořák, F.; Camellone, M. F.; Tovt, A.; Tran, N. D.; Negreiros, F. R.; Vorokhta, M.; Skála, T.; Matolínová, I.; Mysliveček, J.; Matolín, V.; et al. Creating Single-Atom Pt-Ceria Catalysts by Surface Step Decoration. Nat. Commun. 2016, 7. 10801.

(32) Li, X.; Jia, P.; Wang, T. Furfural: A Promising Platform Compound for Sustainable Production of C4 and C5 Chemicals. ACS Catal. 6, 7621-7640 (2016). 
(33) Bouquillon, S.; Muzart, J. Palladium(0)-Catalyzed Isomerization of (Z)-1,4-Diacetoxy-2-Butene -

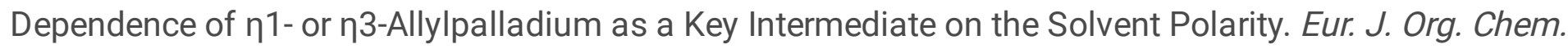
17, 3301-3305 (2001).

(34) Mukhopadhyay, M.; Reddy, M. M.; Maikap, G. C.; lqbal, J. Cobalt(II)-Catalyzed Conversion of Allylic Alcohols/Acetates to Allylic Amides in the Presence of Nitriles. J. Org. Chem. 60, 2670-2676 (1995).

(35) Marion, N.; Gealageas, R.; Nolan, S. P. [(NHC)Au1]-Catalyzed Rearrangement of Allylic Acetates. Org. Lett. 9, 2653-2656 (2007).

(36) Zawisza, A. M.; Bouquillon, S.; Muzart, J. Palladium(II)-Catalyzed Isomerization of (Z)-1,4-Diacetoxy2-Butene: Solvent Effects. Eur. J. Org. Chem. 2, 3901-3904 (2007).

(37) Ishida, T.; Honma, T.; Nakada, K.; Murayama, H.; Mamba, T.; Kume, K.; Izawa, Y.; Utsunomiya, M.; Tokunaga, M. Pd-Catalyzed Decarbonylation of Furfural: Elucidation of Support Effect on Pd Size and Catalytic Activity Using in-Situ XAFS. J. Catal. 374, 320-327 (2019).

(38) Datye, A. K.; Jones, J.; Pereira Hernandez, X. I.; Challa, S. R.; Pham, H.; Oh, S.; Qi, G.; Wiebenga, M. H.; Xiong, H.; DeLaRiva, A. T.; et al. Thermally Stable Single-Atom Platinum-on-Ceria Catalysts via Atom Trapping. Science 353, 150-154 (2016).

(39) Kunwar, D.; Zhou, S.; Delariva, A.; Peterson, E. J.; Xiong, H.; Pereira-Hernández, X. I.; Purdy, S. C.; Ter Veen, R.; Brongersma, H. H.; Miller, J. T.; et al. Stabilizing High Metal Loadings of Thermally Stable Platinum Single Atoms on an Industrial Catalyst Support. ACS Catal. 9, 3978-3990 (2019).

(40) Gracia, F. J.; Miller, J. T.; Kropf, A. J.; Wolf, E. E. Kinetics, FTIR, and Controlled Atmosphere EXAFS Study of the Effect of Chloride on Pt-Supported Catalysts during Oxidation Reactions. J. Catal. 209, 341354 (2002).

(41) Ismagilov, Z. R.; Yashnik, S. A.; Startsev, A. N.; Boronin, A. I.; Stadnichenko, A. I.; Kriventsov, V. V.; Kasztelan, S.; Guillaume, D.; Makkee, M.; Moulijn, J. A. Deep Desulphurization of Diesel Fuels on Bifunctional Monolithic Nanostructured Pt-Zeolite Catalysts. Catal. Today 144, 235-250 (2009).

(42) Zhu, X.; Cheng, B.; Yu, J.; Ho, W. Halogen Poisoning Effect of Pt-TiO 2 for Formaldehyde Catalytic Oxidation Performance at Room Temperature. Appl. Surf. Sci. 364, 808-814 (2016).

(43) Shi, H.; Gutiérrez, O. Y.; Yang, H.; Browning, N. D.; Haller, G. L.; Lercher, J. A. Catalytic Consequences of Particle Size and Chloride Promotion in the Ring-Opening of Cyclopentane on $\mathrm{Pt} / \mathrm{Al}_{2} \mathrm{O}_{3}$. ACS Catal. 3, 328-338 (2013).

(44) Lee, J.; Ryou, Y.; Chan, X.; Kim, T. J.; Kim, D. H. How Pt Interacts with $\mathrm{CeO}_{2}$ under the Reducing and Oxidizing Environments at Elevated Temperature: The Origin of Improved Thermal Stability of $\mathrm{Pt} / \mathrm{CeO}_{2}$ Compared to $\mathrm{CeO}_{2}$. J. Phys. Chem. C120, 25870-25879 (2016). 
(45) Bruix, A.; Rodriguez, J. A.; Ramírez, P. J.; Senanayake, S. D.; Evans, J.; Park, J. B.; Stacchiola, D.; Liu, P.; Hrbek, J.; Illas, F. A New Type of Strong Metal-Support Interaction and the Production of $\mathrm{H}_{2}$ through the Transformation of Water on $\mathrm{Pt} / \mathrm{CeO}_{2}(111)$ and $\mathrm{Pt} / \mathrm{CeO}_{x} / \mathrm{TiO}_{2}(110)$ Catalysts. J. Am. Chem. Soc. 134, 8968-8974 (2012).

(46) Brown, M.; Peierls, R. E.; Stern, E. A. White Lines in X-ray Absorption. Phys. Rev. B 15, 738-744 (1977).

(47) Bruix, A.; Lykhach, Y.; Matolínová, I.; Neitzel, A.; Skála, T.; Tsud, N.; Vorokhta, M.; Stetsovych, V.; Ševčíková, K.; Mysliveček, J.; et al. Maximum Noble-Metal Efficiency in Catalytic Materials: Atomically Dispersed Surface Platinum. Angew. Chem. Int. Ed. 53, 10525-10530 (2014).

(48) Lieske, H.; Lietz, G.; Spindler, H.; Völter, J. Reactions of Platinum in Oxygen- and Hydrogen-Treated Pt $\gamma-\mathrm{Al}_{2} \mathrm{O}_{3}$ catalysts. I. Temperature-Programmed Reduction, Adsorption, and Redispersion of Platinum. J. Catal. 81, 8-16 (1983).

(49) Gao, Y.; Wang, W.; Chang, S.; Huang, W. Morphology Effect of $\mathrm{CeO}_{2}$ Support in the Preparation, MetalSupport Interaction, and Catalytic Performance of $\mathrm{Pt} / \mathrm{CeO}_{2}$ Catalysts. ChemCatChem 5, 3610-3620 (2013).

(50) Acerbi, N.; Tsang, S. C. E.; Jones, G.; Golunski, S.; Collier, P. Rationalization of Interactions in Precious Metal/Ceria Catalysts Using the d-Band Center Model. Angew. Chem. Int. Ed. 52, 7737-7741 (2013).

(51) $\mathrm{Hu}, \mathrm{Z}$.; Metiu, H. Halogen Adsorption on $\mathrm{CeO}_{2}$ : The Role of Lewis Acid-Base Pairing. J. Phys. Chem. C 116, 6664-6671 (2012).

(52) Futatsugi, K.; Yamamoto, H. Oxazaborolidine-Derived Lewis Acid Assisted Lewis Acid as a MoistureTolerant Catalyst for Enantioselective Diels-Alder Reactions. Angew. Chem. Int. Ed. 44, 1484-1487 (2005).

(53) Honma, T.; Oji, H.; Hirayama, S.; Taniguchi, Y.; Ofuchi, H.; Takagaki, M. Full-Automatic XAFS Measurement System of the Engineering Science Research II Beamline BL14B2 at SPring-8. AIP Conf. Proc. 1234, 13-16 (2010).

(54) Oji, H.; Taniguchi, Y.; Hirayama, S.; Ofuchi, H.; Takagaki, M.; Honma, T. Automatic XAFS Measurement System Developed at BL14B2 in SPring-8. J. Synchrotron Radiat. 19, 54-59 (2012).

(55) Gaussian 09, Revision A.02, M. J. Frisch, G. W. Trucks, H. B. Schlegel, G. E. Scuseria, M. A. Robb, J. R. Cheeseman, G. Scalmani, V. Barone, G. A. Petersson, H. Nakatsuji, X. Li, M. Caricato, A. Marenich, J. Bloino, B. G. Janesko, R. Gomperts, B. Mennucci, H. P. Hratchian, J. V. Ortiz, A. F. Izmaylov, J. L. Sonnenberg, D. Williams-Young, F. Ding, F. Lipparini, F. Egidi, J. Goings, B. Peng, A. Petrone, T. Henderson, D. Ranasinghe, V. G. Zakrzewski, J. Gao, N. Rega, G. Zheng, W. Liang, M. Hada, M. Ehara, K. Toyota, R. Fukuda, J. Hasegawa, M. Ishida, T. Nakajima, Y. Honda, O. Kitao, H. Nakai, T. Vreven, K. Throssell, J. A. 
Montgomery, Jr., J. E. Peralta, F. Ogliaro, M. Bearpark, J. J. Heyd, E. Brothers, K. N. Kudin, V. N. Staroverov, T. Keith, R. Kobayashi, J. Normand, K. Raghavachari, A. Rendell, J. C. Burant, S. S. Iyengar, J. Tomasi, M. Cossi, J. M. Millam, M. Klene, C. Adamo, R. Cammi, J. W. Ochterski, R. L. Martin, K. Morokuma, O. Farkas, J. B. Foresman, and D. J. Fox, Gaussian, Inc., Wallingford CT, 2016.

(56) Kresse, G.; Furthmüller, J. Efficient Iterative Schemes for Ab Initio Total-Energy Calculations Using a Plane-Wave Basis Set. Phys. Rev. B. 54, 11169-11186 (1996).

(57) Kresse, G.; Furthmüller, J. Efficiency of Ab-Initio Total Energy Calculations for Metals and Semiconductors Using a Plane-Wave Basis Set. Comput. Mater. Sci. 6, 15-50 (1996).

(58) Blöchl, P. E. Projector Augmented-Wave Method. Phys. Rev. B 50, 17953-17979 (1994).

(59) Perdew, J. P.; Burke, K.; Ernzerhof, M. Generalized Gradient Approximation Made Simple. Phys. Rev. Lett. 77, 3865-3868 (1996).

(60) McFarland, E. W.; Metiu, H. Catalysis by Doped Oxides. Chem. Rev. 113, 4391-4427 (2013).

\section{Table}

Table 1 is available in the Supplementary Files

\section{Figures}

a
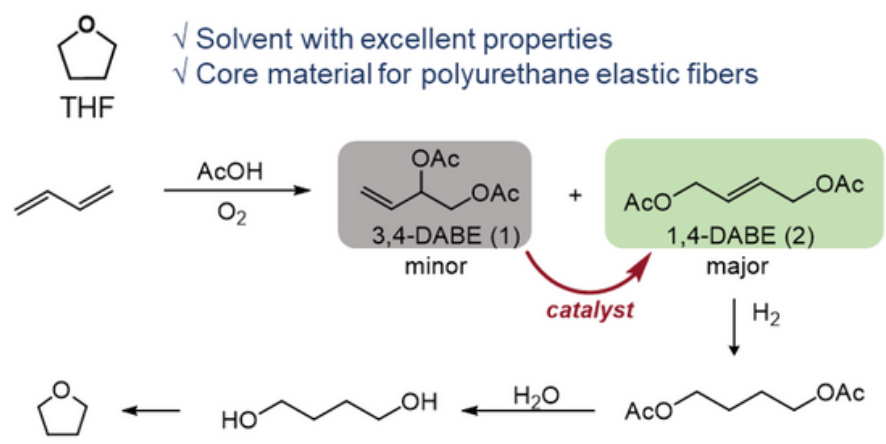

C This research: Developing active heterogeneous catalysts via the soft Lewis scid transition state

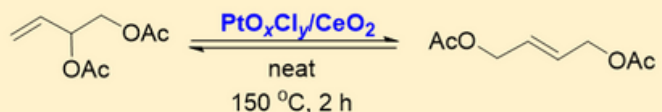

$\sqrt{ }$ Solvent-free $\quad \sqrt{ }$ Reusable $\quad$ TON $=5400$ b Previous methods with homogeneous catalysts i. via the $\pi$-allyl intermediate

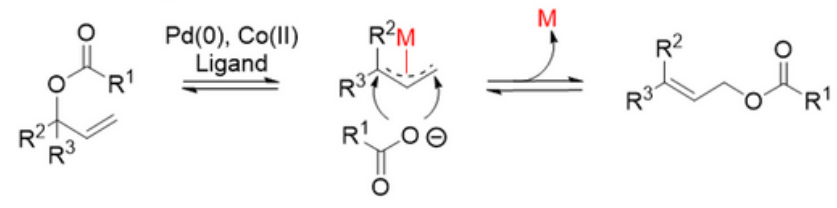

ii. via the soft Lewis acid transition state
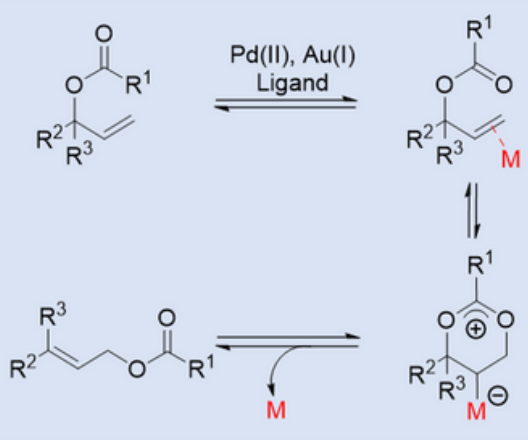

$\times$ Solvent-free $\quad \times$ Reusable

TON: 6-30 
A sustainable transformation: isomerization of allylic esters with efficient soft Lewis acid catalysts. a, A C4 chemical reaction route from buta-1,3-diene. b, Reaction with homogeneous catalysts. c, Research of efficient supported soft Lewis acid catalysts.
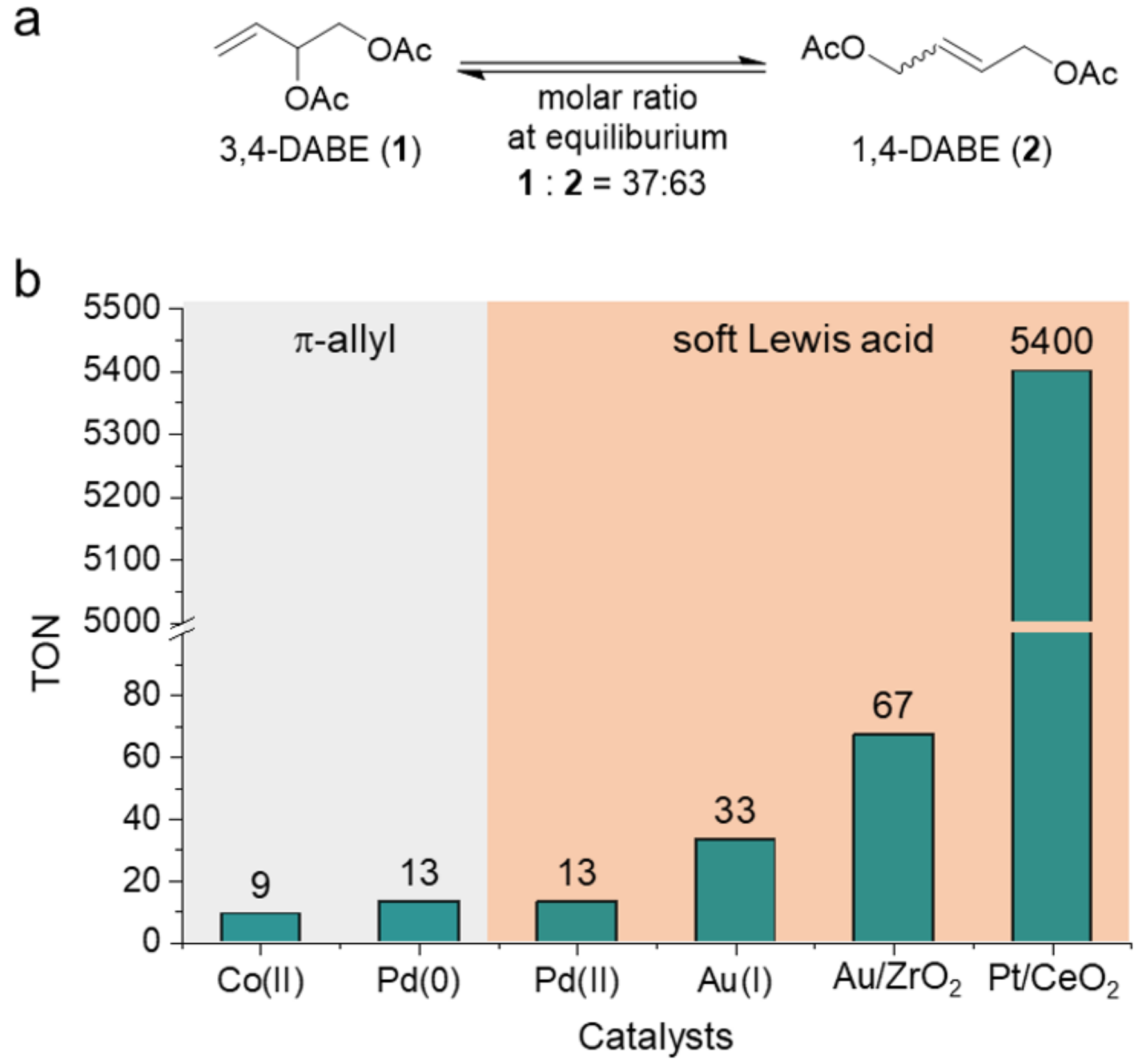

Figure 2

Evaluation of catalytic activity. a, Equilibrium of 3,4-DABE and 1,4-DABE. b, Turnover number (TON) for the catalyst prepared in this study $(\mathrm{Au} / \mathrm{ZrO} 2$ and $\mathrm{Pt} / \mathrm{CeO} 2)$ and those in previous reports (homogeneous catalysts of $\mathrm{Co}(\mathrm{II}), \mathrm{Pd}(0), \mathrm{Pd}(\mathrm{II}), \mathrm{Au}(\mathrm{I})) 33-36$. See Supplementary Table 3 for further details. 

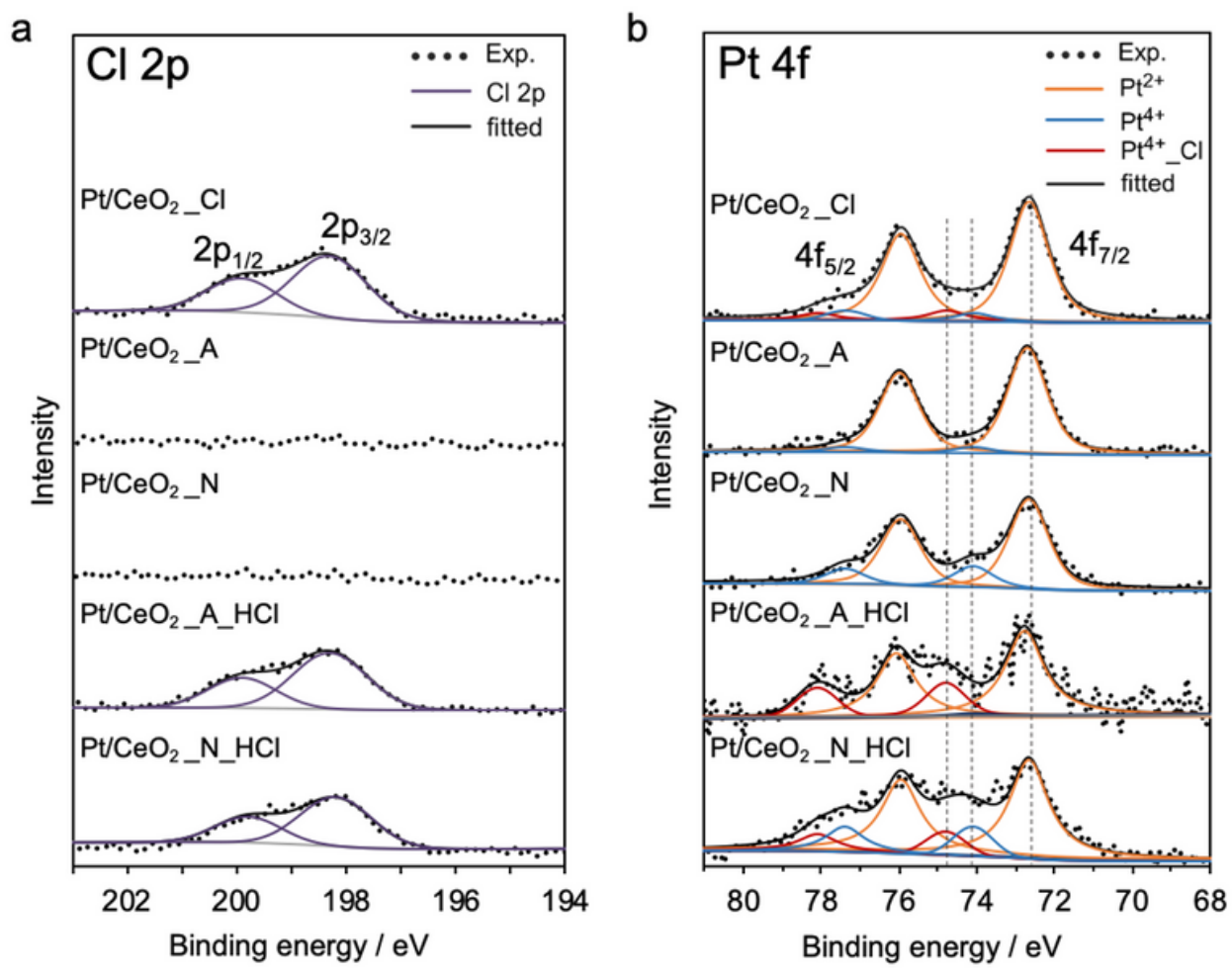

C
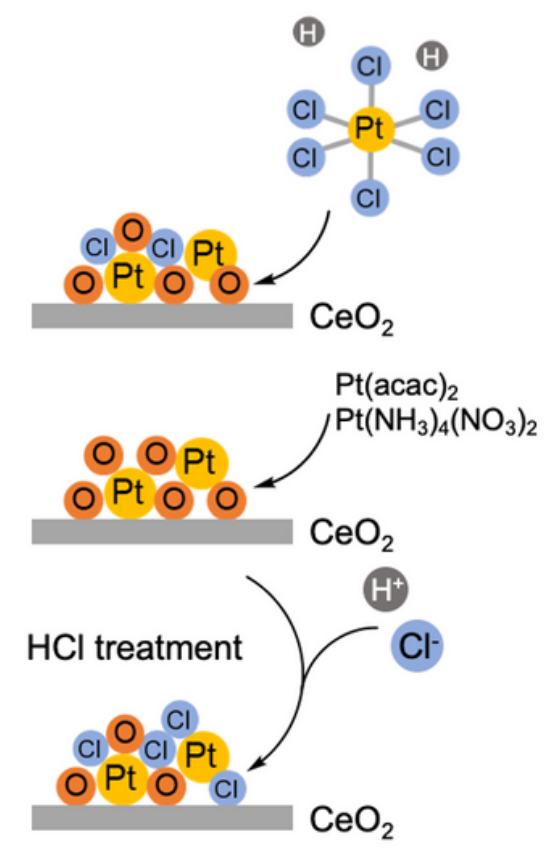

Figure 3

XPS spectra of $1 \mathrm{wt} \% \mathrm{Pt} / \mathrm{CeO} 2$ prepared from various precursors or $\mathrm{Cl}$-free catalysts with $\mathrm{HCl}$ posttreatment. a, Spectra of $\mathrm{Cl} 2 \mathrm{p}$. b, Spectra of Pt 4f. c, Simple structural model correlates the XPS spectra of three types of catalysts. 
a
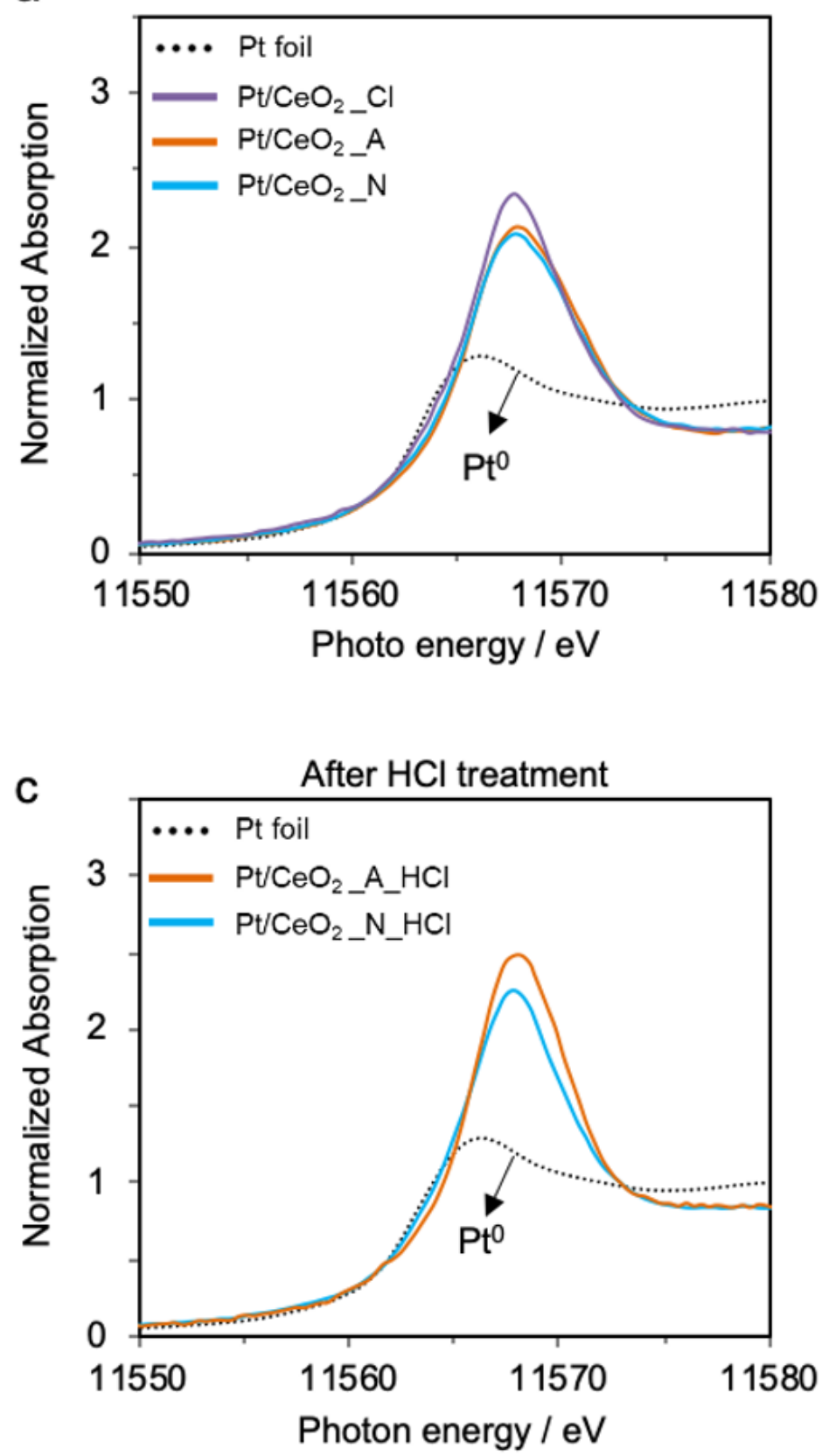

b

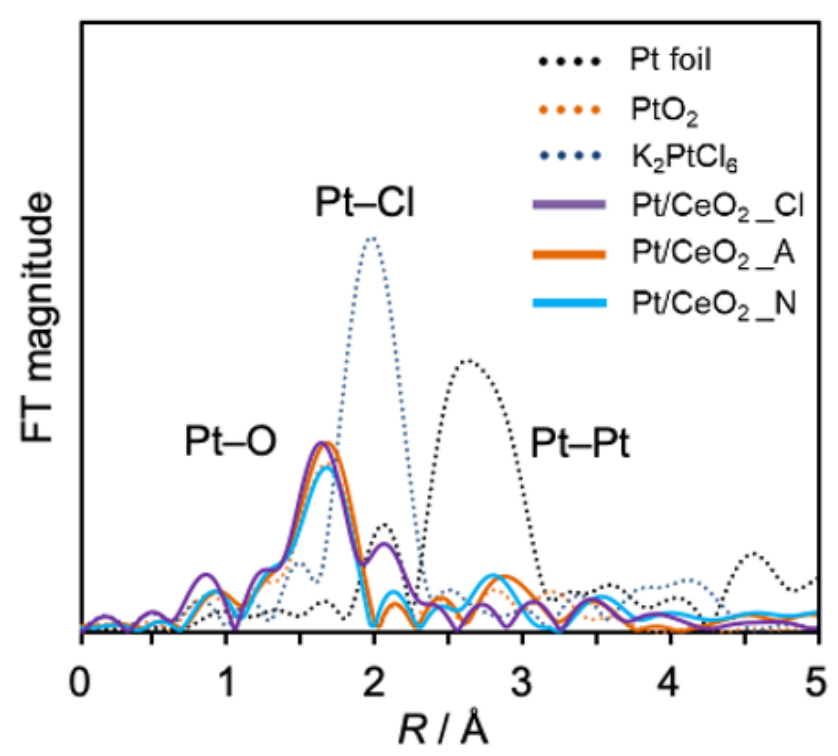

d

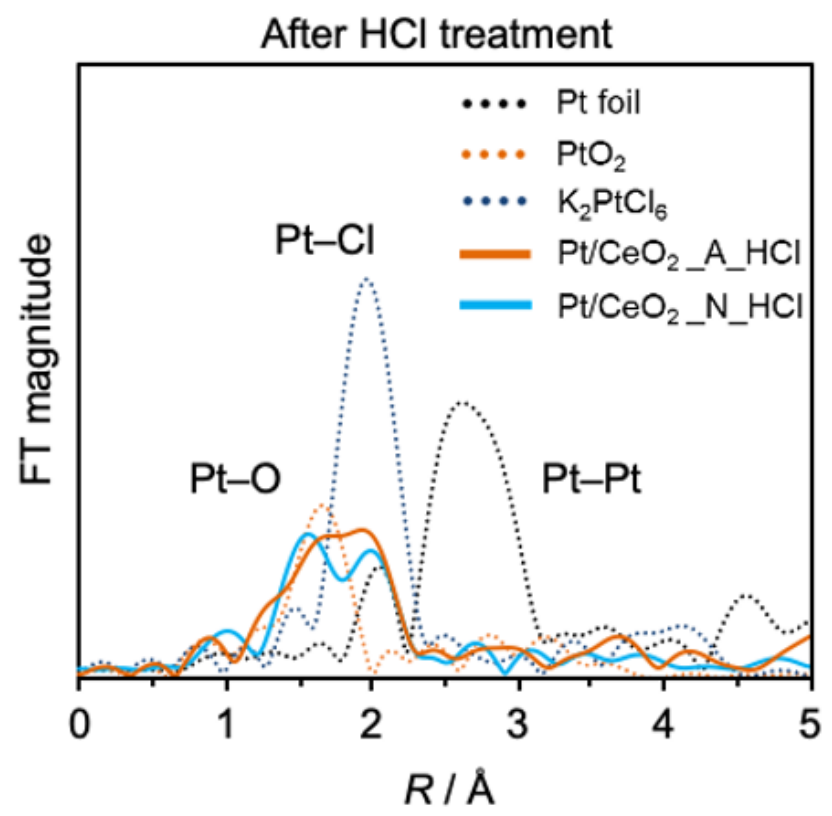

Figure 4

Pt LIII-edge XANES spectra and radial structure functions of Pt/CeO2 $(k=3-13 \AA-1)$. a,b, prepared from different pre-cursors; c,d, $\mathrm{HCl}$-treated $\mathrm{Pt} / \mathrm{CeO} 2$ prepared from $\mathrm{Cl}$-free precursors. 


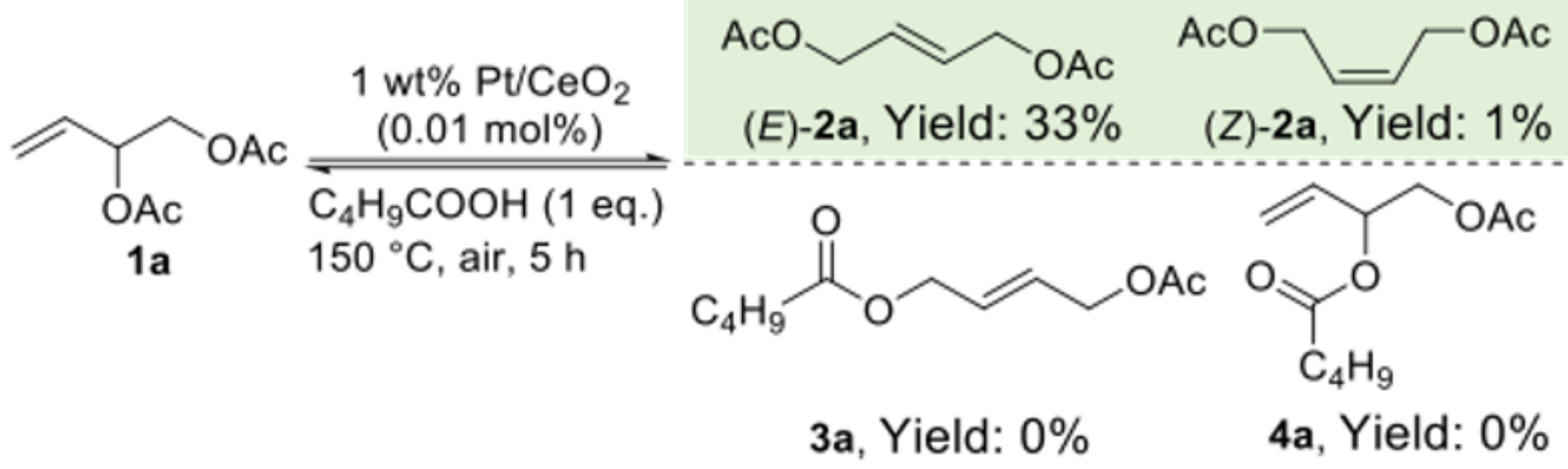

Figure 5

Reaction mechanism investigation by the addition of valeric acid. 
a

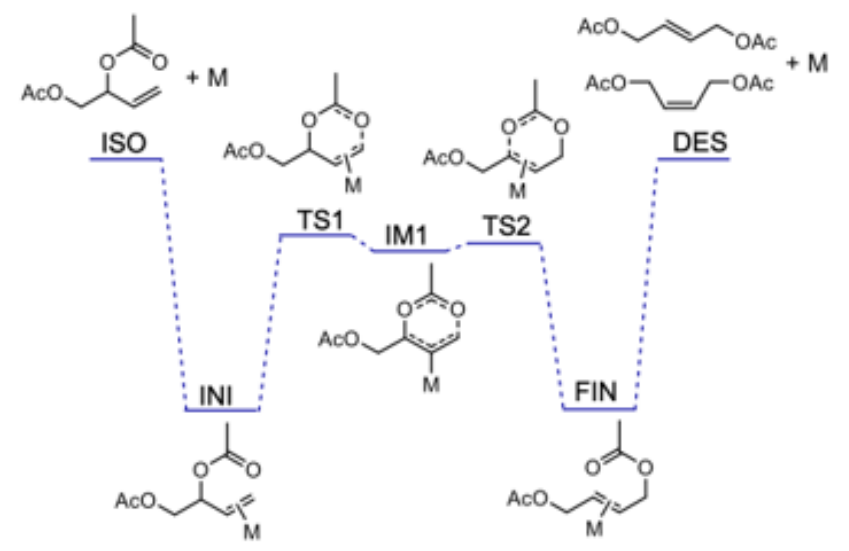

b

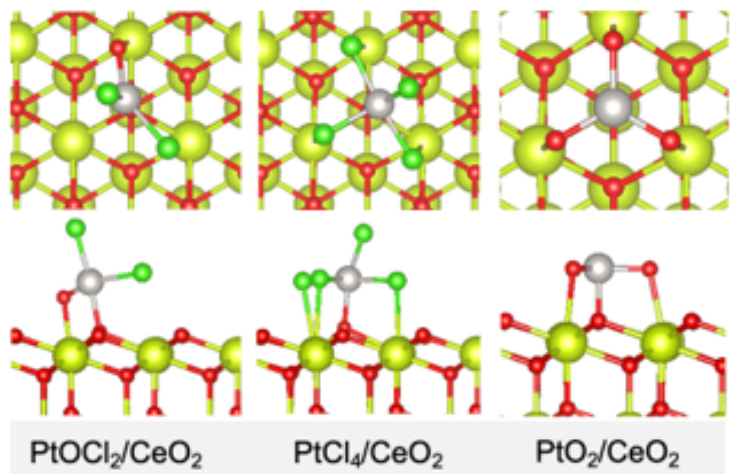

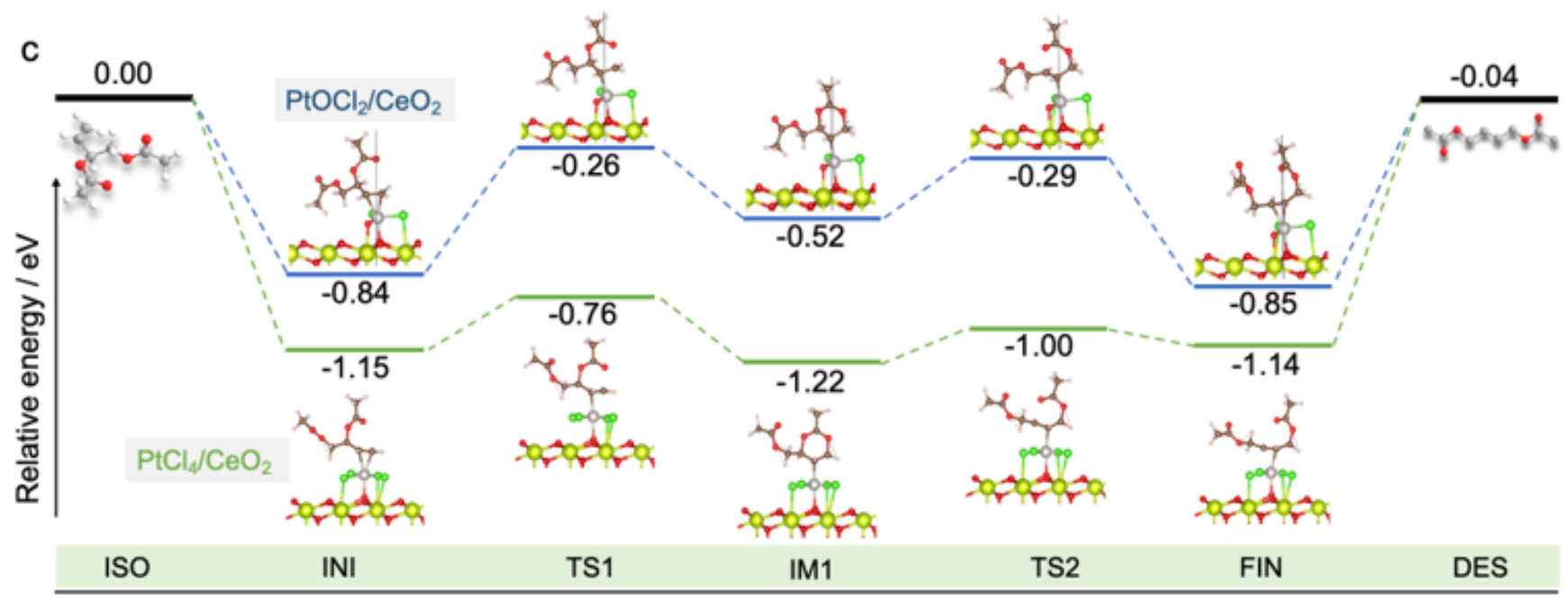

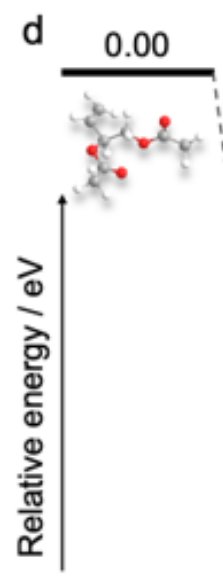

ISO

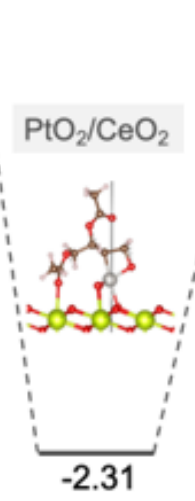

INI (di- $\sigma)$
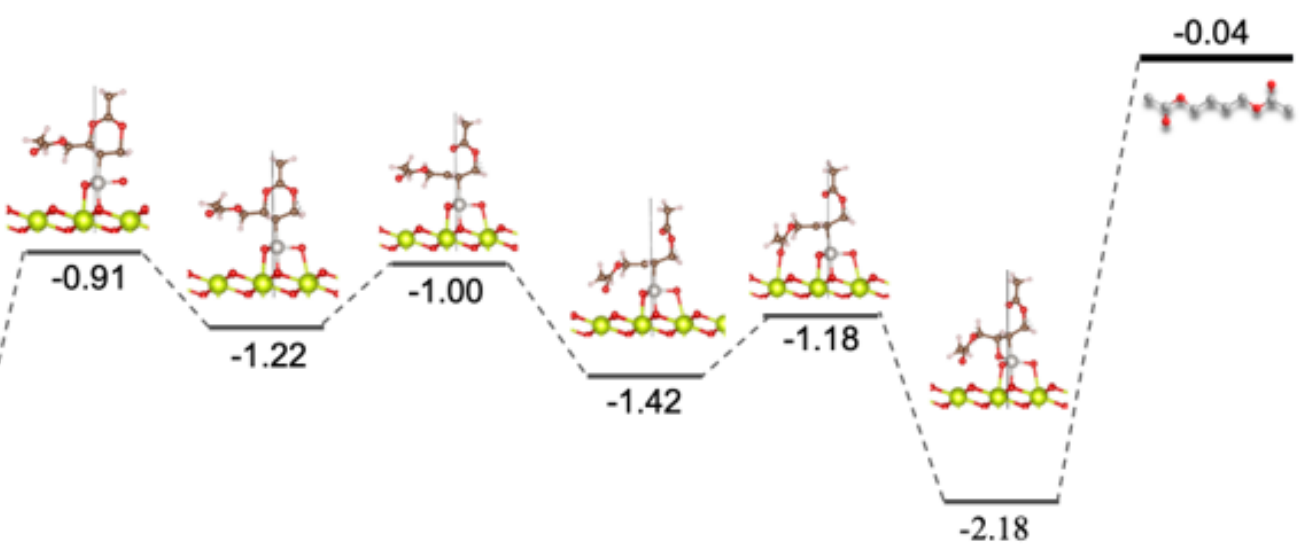

IM1

TS2

$\operatorname{FIN~}(\pi) \quad$ TS $(\pi \rightarrow$ di- $\sigma) \quad$ FIN $($ di- $\sigma)$

DES

\section{Figure 6}

Calculation for isomerization of 3,4-DABE on supported Pt/CeO2 catalysts. a, Basic transition states of the catalytic isomerization of 3,4-DABE on the cluster model. b, Top and side views of atomic Pt-Cl and Pt-O species on CeO2(111). Col-or: Pt, gray; Ce, yellow; oxygen, red; chlorine, green. c, Diagram of the energy calculation of the transition states on the model catalysts $\mathrm{PtOCl} 2 / \mathrm{CeO} 2$ and $\mathrm{PtCl} 4 / \mathrm{CeO} 2$. d, Diagram of the energy calculation of the transition states on the model cat-alyst PtO2/CeO2. 


\section{Supplementary Files}

This is a list of supplementary files associated with this preprint. Click to download.

- Table1.png

- PtNCSI0925.docx

- TableofContents.png 